\title{
A rare sequela of chronic pseudo-obstruction
}

\author{
Matthew Arneill, ${ }^{1}$ Philip Wilson, ${ }^{1}$ Derek Hennessey, ${ }^{2}$ Emanuel Epanomeritakis ${ }^{3}$
}

'Department of General Medicine, Craigavon Area Hospital, Armagh, UK

${ }^{2}$ Department of Urology, Craigavon Area Hospital Armagh, UK

${ }^{3}$ Department of General Surgery, Craigavon Area Hospital, Armagh, UK

\section{Correspondence to}

Derek Hennessey,

derek.hennessey@gmail.com

\section{DESCRIPTION}

We report the case of a 67-year-old man with chronic pseudo-obstruction who presented to hospital with bilateral lower leg cellulitis. His medical history included depression and anxiety. Surgical history included a perforated sigmoid volvulus that required an emergency laparotomy and Hartmann's procedure 16 years previously. The end colostomy was subsequently reversed 1 year later. Five years following that, the patient experienced symptoms of pseudo-obstruction requiring hospitalisation and decompression with flatus tube insertion.

On examination the patient was comfortable with all observations within normal range. His abdomen was soft, non-tender and distended. No abnormality was detected on digital rectal examination. A routine chest X-ray showed a markedly abnormal left hemithorax filled with air, and mediastinal shift to the right (figure 1). CT of the chest demonstrated markedly dilated colon lying in the left hemithorax causing mediastinal shift to the right and left lung collapse (figure 2). A water soluble enema demonstrated evidence of pseudo-obstruction with transverse colon lying in the left hemithorax. Flexible sigmoidoscopy was carried out with good decompression of the large bowel. This case demonstrates a most unusual complication of chronic pseudo-obstruction, with a large paraoesophageal hernia developing due to lack of capacity of the peritoneal cavity to accommodate the chronically dilated colon.

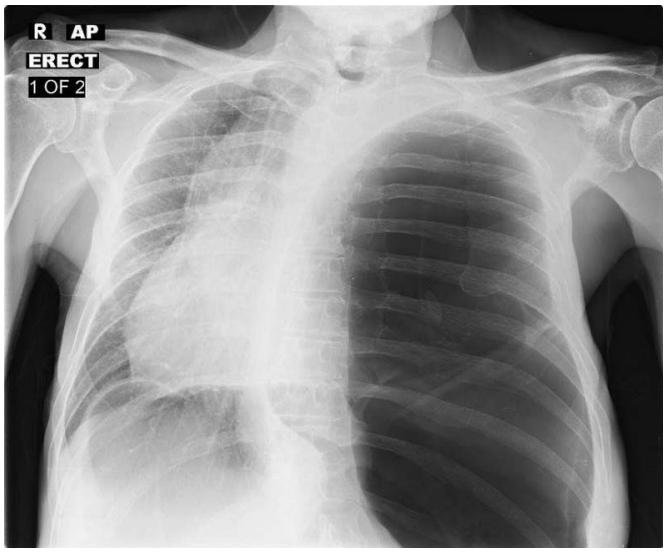

Figure 1 Markedly abnormal chest X-ray with an air-filled left hemithorax and mediastinal shift to the right-hand side.

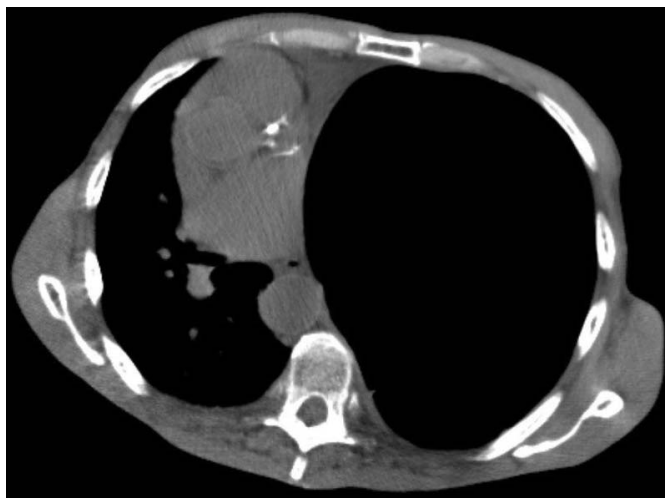

Figure 2 Axial image from the subsequent CT scan at the level of $\mathrm{T} 5$ in the mediastinal window demonstrating bowel in the left hemithorax, left lung collapse and mediastinal shift.

The most serious potential complication is bowel strangulation and perforation. ${ }^{1}$ Surgical management takes the form of laparoscopic or open paraoesophageal hernia repair, mesh repair of the defect and colopexy. ${ }^{2} 3$ This case demonstrates a rare finding on chest X-ray that may be easily misdiagnosed.

\section{Learning points}

A chest X-ray of this appearance must prompt consideration of tension pneumothorax, large lung bulla and paraoesophageal hernia as potential causes.

- Paraoesophageal hernia may rarely present as a complication of chronic pseudo-obstruction.

- Surgical correction may take the form of mesh repair and colopexy.

Competing interests None.

Patient consent Obtained.

Provenance and peer review Not commissioned; externally peer reviewed.

\section{REFERENCES}

1 Kelly J, Condon E, Kirwan W, et al. Post-traumatic tension faecopneumothorax in a young male: case report. World J Emerg Surg 2008:3:20.

2 Oelschlager B, Petersen R, Brunt M, et al. Laparoscopic paraoesophageal hernia repair: defining long term clinical and anatomic outcomes. JGastrointest Surg 2012;16:453-9.

3 Hennessey D, Convie L, Barry M, et al. Paraoesphageal hernia: an overview. Br J Hosp Med (Lond) 2012:73:437-40. 
Copyright 2014 BMJ Publishing Group. All rights reserved. For permission to reuse any of this content visit http://group.bmj.com/group/rights-licensing/permissions.

BMJ Case Report Fellows may re-use this article for personal use and teaching without any further permission.

Become a Fellow of BMJ Case Reports today and you can:

- Submit as many cases as you like

- Enjoy fast sympathetic peer review and rapid publication of accepted articles

- Access all the published articles

- Re-use any of the published material for personal use and teaching without further permission

For information on Institutional Fellowships contact consortiasales@bmjgroup.com

Visit casereports.bmj.com for more articles like this and to become a Fellow 